Јован Ј. Алексић

Филозофски факултет

Универзитета у Приштини

са привременим седиштем

у Косовској Митровици

докторанд

aleksicjovan@rocketmail.com

930.85(495.115 Косовска Митровица)"1999/2017" https://doi.org/10.18485/ai_san_o_gradu.2018.ch25

\title{
КОСОВСКА МИТРОВИЦА ПОСЛЕ 1999. ГОДИНЕ: ЖИВЕТИ У ПОДЕЉЕНОМ ГРАДУ
}

Косовска Митровица, родно место аутора овог рада, данас представља прави научни изазов бројним политиколозима, социјалним психолозима и антрополозима, који се њоме углавном баве кроз призму проблематике подељеног града. Како је до тога дошло? Зашто је „најлепша варош Косовска“, како је једном приликом Нушић назвао, доживела судбину Мостара, Белфаста, Јерусалима, Хаифе, Бејрута...? Да ли је њеном поделом на северни, углавном српски, и јужни, готово искључиво албански део града, у овој средини заувек уништен андрићевски „сан о граду“ свих оних који су га, поред свега, искрено волели? Да ли је тако морало бити? Или су то, једноставно, животне (после)ратне околности наметнуле? Како на све то гледају „обични“, „мали“ људи? Како изгледа њихов живот? Како се они суочавају са бројним проблемима у овој специфичној урбаној (полу)целини? Да ли после свега што су преживели могу размишљати о некој срећнијој будућности у свом граду? Потенцијални одговори на наведена питања могу се наслутити ишчитавањем овог рада, који је написан на основу доступних историјских извора, штампе и релевантне литературе.

Кључне речи: Косовска Митровица, Косово и Метохија, север Косова, мост, конфликт. 
Једном је Иво Андрић записао да су мостови „руке које спајају обале и људе, скраћују путеве и представљају лепоту једног града“. Обично је заиста тако, поготово ако имамо у виду његову славом овенчану вишеградску ћуприју, „Tower Bridge“ у Лондону, „Водени мост“ у Магдебургу, „Карлов мост“ у Прагу, „Brooklyn Bridge“ у Њујорку, „Golden Gate“ у Сан Франциску, „Нанпу“ у Шангају... Међутим, Андрић није био (скроз) у праву. Некада мостови не служе својој намени. Некада не врше своју племениту мисију. Некада је можда боље да нису ни саграђени. Постоје примери који показују да се управо у њима огледа сва парадоксалност различитих сукоба око неких мање-више ситних, овоземаљских интереса. Тада се симболика мостова претвара у своју супротност: уместо да спајају, они раздвајају; уместо да зближавају, они удаљавају. Управо је такав случај са главним мостом на Ибру у Косовској Митровици. Ова, по разним сукобима и инцидентима позната грађевина, пуних 18 година дели поменути град на јужни, готово искључиво албански и северни, углавном српски део града. На неки начин симболише сву сложеност косовско-метохијског питања, свих несрећа, подела и проблема два комшијска народа. Како је до тога дошло?

Током лета 1999. године, након НАТО бомбардовања, потписивања Кумановског споразума и доношења Резолуције 1244, повлачења оружаних снага СР Југославије, протеривања више од 250.000 Срба и других неалбанаца, мост у Косовској Митровици постао је поприште сталних сукоба Срба и Албанаца. Велики број Срба протераних из разних делова Косова и Метохије, као и из јужног дела овог града, настанио се на његовој северној страни, чврсто решећи да ту остане („даље немамо куд“). Насупрот томе, албански екстре- 
мисти из јужног дела града су врло често вршили нападе на српске становнике северног дела града, желећи да их одатле протерају и заузму последњу српску урбану зону на Косову и Метохији. ${ }^{1}$ Преостали Срби су се самоорганизовали, основали неформалне групе за заштиту својих породица и сународника („чувари моста“, „мостаџије“) и бранили како су знали и умели најчешће моткама, шипкама и камењем, а понекад и својим телима (Јевтимијевић 2008: 462-476). Првих годину дана након рата, масовни сукоби на мосту били

1 Треба рећи да је пре ратних сукоба 1999. године Косовска Митровица била изразито хетерогена средина када је у питању национални и конфесионални састав становништва. Осим кварта познатог по имену Фабричка улица у којем су боравили искључиво Роми, у осталим деловима града измешано су живели Срби, Албанци, Турци, Бошњаци, Горанци, Ашкалије... Истини за вољу, највећи број Срба је и тада живео на северној страни града, а највећи број Албанаца на јужној, али су са обе стране Ибра били раштркани и једни и други. После рата се то радикално променило. Срби из јужног дела града, али и Роми, Бошњаци, Ашкалије и Горанци протерани су из својих домова и били приморани да се настане у северном делу града. Исто тако, непосредно за време ратних дејстава одређени број Албанаца из северног дела града је или напустио или био протеран из својих кућа и станова. У њих су се касније уселили углавном прогнани становници јужног дела града, али и других насеља Косова и Метохије (највише из Вучитрна, Пећи, Истока, Приштине, Гњилана, Призрена и обода Косовске Митровице). Ипак, значан број Албанаца је остао на северној страни града, где живи и дан-данас (према проценама ОЕБС-а, више од 4.500). На тај начин је јужни део града остао готово потпуно албански, етнички чист, а северни мултинационални и мултиконфесионални, али са српском већином (према подацима ОЕБС-а из 2011. године, у северном делу Косовске Митровице живело је око 22.530 Срба, 4.900 Албанаца, 1.000 Бошњака, 580 Горанаца, 210 Турака, 200 Рома и 40 Ашкалија). - Mitrovicë/Mitrovica Municipal Profile, OSCE, November 2011 http://www.osce. org/kosovo/38678, приступљено 12. 12. 2012. године у 20: 25 h 
су свакодневица. ${ }^{2}$ Први насилан покушај преласка Албанаца из јужног дела града у северни збио се 26. јуна 1999. године (Vlašković-Lazarević 2005: 5). Услед одлучног отпора Срба, он је пропао. Међутим, то Албанце није нимало поколебало. Свега 11 дана касније, након посете Веслија Кларка, тадашњег команданта НАТО-а за југоисточну Европу, организовали су тзв. „Марш мира“, уз подршку представника међународне заједнице. Тада је више од 5.000 Албанаца први и једини пут организовано продефиловало северном страном града. Иако су од припадника француског састава КФОР-а добили препоруку да не излазе из својих домова, готово сви одрасли грађани северног дела града изашли су на своје улице, спремни да их бране уколико за то буде потребе. У прилично узаврелој атмосфери, где је фалила само искрица да запали пламен великог масовног сукоба, између неколико хиљада Срба и Албанаца формирана су два кордона који су чинили припадници француског КФОР-а. Осим буке, звиждука и размене вербалних увреда, све је завршено релативно мирно. Албанци су прошли улицама Краља Петра I, Кнеза Милоша, прешли преко источног моста на јужну страну града, где су их дочекали униформисани припадници тзв. „Ослободилачке војске Косова“ (алб. Ushtria Çlirimtare e Kosovës - UÇK) (https://www.youtube.com/ watch? $=5$ tfMFhFiLMc\&t=11s, приступљено 25.11. 2017. године у 22:33 h). До краја година на самом мосту

2 Више о томе видиу: - https://www.youtube.com/watch?v=PisnzsOQbIw, приступљено 25. 11. 2017. године у 20: $25 \mathrm{~h}$; https://www. youtube.com/watch?v=5kQXEG2rSpk, приступљено 25.11. 2017. године у 20: $42 \mathrm{~h}$; https://www.youtube.com/watch?v=uzIYRFQByEs, приступљено 25. 11. 2017. године у 20: 49 h; https:// www.youtube.com/watch?v=FlTeiFCN7dc, приступљено 25. 11. 2017. године у 20: 57 h; https://www.youtube.com/watch?v=W6L4wb22vAo, приступљено 25. 11. 2017. године у 21: 43 h; 
десило се још 13 великих инцидената, од којих је најжешћи био 10. септембра, када је повређено тридесет троје Срба, петнаест војника КФОР-а и око четрдесет Албанаца (Vlašković-Lazarević 2005: 6).

Нови миленијум није донео мир. Сукоби су се наставили. Након многобројних чарки, провокација и туча током јануара, освануо је један од најцрњих дана у новијој историји Косовске Митровице - 3. фебруар 2000. године. У популарни кафић „Белами“, где су се углавном окупљали локални средњошколци и студенти, око 20:30 ч. бачене су две бомбе, од којих је једна експлодирала. Према различитим информацијама, повређено је између 11 и 19 младића и девојака српске националности, од којих петоро тешко. Чувши шта се десило, њихови родитељи, рођаци, комшије и пријатељи, избезумљени од ужасних вести, панике, страха и беса, изашли су на улице и од „уста до уста““ ширили глас суграђанима да им се придруже. ${ }^{3}$ Око 22:30 ч. на улицама северног дела Косовске Митровице било је већ неколико хиљада људи. Први на мети гневних, од многих стресова распамећених Митровчана, нашли су се они који су, барем формално, били задужени за њихову безбедност - КФОР, УНМИК, ОЕБС. Летеле су каменице, флаше, цигле, мотке и молотовљеви коктели. Плануло је неколико десетина скупоцених џипова и демолира-

3 Треба имати у виду да се два дана пре тога десио терористички напад на аутобус УНХЦР-а, који је превозио Србе од Косовске Митровице до Сувог Грла, приликом којег је на лицу места настрадало двоје Срба, Плана Рајковић и Будимир Јовановић, док су Милојка Ристић и Стојан Томашевић остали без руку и ногу. То је, свакако, утицало да се међу потпуно незаштићеним и обесправљеним Србима подигне атмосфера огорчености, страха и панике, која је кулминирала бомбашким нападом на кафић у којем се окупљала њихова омладина. - http://www.nin.co.rs/2000-02/10/11513.html, приступљено 26. 11. 2017. године у 12:23 h. 
но десетак канцеларија међународних организација. О размерама разјарености грађана северне Косовске Митровице говори и податак да су се чак и припадници КФОР-а у оклопним возилима повукли у јужни део града, страхујући за своју егзистенцију. А онда је, у таквој, крајње запаљивој атмосфери, међу масом прострујала још једна лоша вест - тринаестогодишњак српске националности је киднапован и држи се као таоц у албанском стану. То је била кап која је прелила чашу. У необузданом осветничком гневу Срба, те ужасне ноћи убијено је, према различитим информацијама, између три и шест Албанаца и двоје Турака, док је седам Албанаца повређено. До сутрашњег дана, повређено је још неколико Срба, тако да је број лакше и теже повређених са српске стране сутрадан износио двадесет пет. (http:// www.nin.co.rs/2000-02/10/11513.html, приступљено 26. 11. 2017. године у 12:23 h; https://www.b92.net/info/vesti/ index.php? yyy $=2000 \& \mathrm{~mm}=02 \& \mathrm{dd}=04 \&$ nav $\mathrm{id}=4386$, приступљено 26. 11. 2017. године у 12:23 h). Али, ни то није био крај бурних дешавања у граду на ушћу Ситнице у Ибар. Сутрадан се са јужне стране моста окупило неколико хиљада Албанаца, који су поново покушали насилно прећи на северну страну и обрачунати се са преосталим Србима. Међутим, поучени искуством претходне ноћи, овога пута су безбедносне снаге реаговале адекватно и растерале демонстранте пендрецима, сузавцима, воденим топовима и гуменим мецима. Епилог сукоба је био - једанаест повређених припадника француског и данског КФОР-а и неколико десетина Албанаца (http://www.nin.co.rs/2000-02/10/11513.html, приступљено 26. 11. 2017. године у 12:23 h).

Највећи масовни покушај освајања северног дела Косовске Митровице од стране Албанаца десио се 17 дана касније, 21. фебруара 2000. године. Тада се у јуж- 
ном делу овог града окупило преко 40.000 Албанаца, који су, под фирмом демонстрација „за јединствену Митровицу“ дошли из разних делова Косова и Метохије да се једном за свагда обрачунају са Србима с друге стране Ибра (https://www.youtube.com/watch?v=U4Sug4Q4H0, приступљено 26. 11. 2017. године у 13:36 h). Око 15:30 часова почео је обрачун између албанских демонстраната и припадника КФОР-а. Петнаест минута касније око 5.000 Албанаца пробило је први кордон припадника КФОР-а, који се налазио двадесетак метара од моста, и дошла до саме његове ивице. Кордон од стотинак припадника КФОР-а, као и десетак оклопних транспортера, спречавали су велику масу Албанаца да пређу у северни део града. Истовремено, српско становништво је такође почело да се окупља у близини моста, спремно да се брани. За непуних сат времена са северне стране моста окупило се око седам хиљада Срба. Митровчанима су у помоћ пристизали Звечанци, Лепосавци, Колашинци... Сви свесни да је тај дан можда пресудан за опстанак Срба на северу Косова. Јер, ако падне Косовска Митровица - пале су све остале општине северно до Ибра. Албанци су у међувремену шест пута насилно покушали да пробију кордон међународних снага. Око 17:30 ч. почео је и нови, седми сукоб КФОР-а и албанских демонстраната, током којег су међународне снаге поставиле шест тенкова усмерених ка Албанцима. Као и током претходних сукоба, КФОР је на албанске екстремисте поново испаљивао „шок-бомбе“ и сузавац, а Албанци су на припаднике Кфора бацали каменице. Двадесетак метара од јужне стране моста, као и дуж обале Ибра око 18 ч. још се налазило неколико хиљада Албанаца, а војници међународних снага безбедности употребљавали су сузавац, пендреке и „шок-бомбе“ како би растера- 
ли демонстранте. Демонстрације су коначно разбијене око 19 ч. Већ пола сата касније, на улицама јужног дела Косовске Митровице није било организованих група Албанаца. (https://www.b92.net/info/vesti/index. php? yyyy $=2000 \& m m=02 \& d d=21 \&$ nav category $=1 \&$ nav $\underline{\mathrm{id}=4790}$, приступљено 26. 11. 2017. године у 13:49 h). Након тога и Срби са северне стране почели су да се разилазе. Ипак, њих стотинак је провело ноћ крај моста, страхујући од поновног напада са јужне стране. То је био епилог овог бурног дана. Након њега, масовни инциденти на мосту били су ређи. Ипак, и поред тога Албанци су током година много пута насилно покушали да продру у северни део града. Брижљиви локални хроничари су забележили да се од јуна 1999. до јуна 2014. године на мосту десило 118 инцидената, у којима су Албанци 26 пута употребили ватрено оружје (http:// www.politika.rs/scc/clanak/297241/Od-1999-na-mostu-uKosovskoj-Mitrovici-118-incidenata, приступљено 26. 11. 2017. године у 13:57 h). Њихов најпознатији напад догодио се 17. марта 2004. године, нешто после 11 ч. пре подне. Дан када је почео Мартовски погром: појам који је у колективној свести косовско-метохијских Срба остао синоним за страдање, вандализам, насиље, некажњени злочин. А почео је управо у Косовској Митровици.

Званичан повод за напад на Србе био је дављење двоје дечака албанске националности у селу Чабра, у општини Зубин Поток. Према верзији приче њихових вршњака који су наводно били са њима, они су 16. марта 2004. године бежала од деце из суседног српског села Зупче, упала у Ибар и удавила се. Ову причу су оберучке прихватили албански медији на Косову и Метохији и искористили је за стварање ат- 
мосфере линча према Србима. ${ }^{4}$ Сутрадан, 17. марта 2004. године, у јужном делу Косовске Митровице око 11 часова окупило се неколико стотина Албанаца. Пет-

4 Треба нагласити да је каснијом истрагом УНМИК полиције недвосмислено утврђено да су искази албанских дечака били лажни. Они су под притиском албанских медија и политичара били приморани да оптуже Србе из суседног села Зупче, иако они са дављењем двојице Албанаца нису имали никакаве везе (http://www.osce.org/fom/30265, приступљено 26. 11. 2017. године y 15:10 h; http://www.b92.net/specijal/kosovo2004/, приступљено 26. 11. 2017. године у 15:30 h; ). Ипак, у сваком случају, њихова прича била је добар повод албанским екстремистима да започну погром, који је очигледно био унапред планиран и осмишљен. Доказ за то је чињеница да су одмах после атака на северни део Косовске Митровице кренули добро организовани и синхронизовани напади на готово све српске средине на Косову и Метохији. У њима је учествовало око 50.000 Албанаца. За три дана, од 17. до 20. марта 2004. године протерано је неколико хиљада Срба, 8 убијено, а преко 800 кућа спаљено. На мети вандала посебно су биле српске светиње. Запаљено, уништено или оскрнављено је 35 православних храмова, међу којима и Богородица Љевишка, која је била на листи УНЕСКО светске културне баштине. Све се ово дешавало пред очима целог света. Камере домаћих, регионалних и светских медија преносиле су страшне призоре насиља над потпуно невиним људима, њиховом културом и историјом. Декларативне осуде, стерилни „апели на мир и уздржаност" нису много утицали на разуларене масе албанских екстремиста који су рушили све пред собом. Велики број припадника међународних војних снага КФОР-а је, уз часне изузетке, немо посматрао погром над Србима. Остатак Србије је немоћно гледао како се убија њен народ и затире њено културно наслеђе, уз протесте, молебане и безуспешне апеле да се престане са погромом. Представници „међународне заједнице“ немушто су осудили „насиље“ притом не наводећи над ким је насиље вршено. За многобројна злодела над Србима, њиховом имовином, културно-историјским и сакралним споменицима нико од најодговорнијих није изведен пред лице правде (http:// www.rts.rs/page/stories/ci/story/124/drustvo/2668249/trinaest-godina-od-martovskog-pogroma-na-kosovu.html, приступљено приступљено 26. 11. 2017. године у 15:38 h). 
наест минута касније су насилно прешли у српски део града, са све албанском заставом на челу. Правили су велику буку, урлали, узвикивали антисрпске пароле, бацали каменице на околне зграде и становнике, демолирали оближње продавнице и кафиће. Изненађени Срби су из оближњих стамбених зграда, трговинских и угоститељских објеката спонтано јурили ка мосту и некако успели да их потисну у јужни део. Недуго затим, регистровани су први пуцњи из ватреног оружја на Србе из правца „Три солитера“, у северном делу града. Истовремено, албански екстремисти почели су да бацају молотовљеве коктеле на возила УНМИК полиције. Истовремено, албански екстремисти из јужног дела града успели су да пређу у северни преко пешачког моста у близини поменута „Три солитера“, једног од три мултиетничка насеља северне Косовке Митровице („Микронасеље“, „Бошњачка махала“, „Три солитера“). Видевши то, велики део српске масе се покренуо ка том мосту трудећи се да их спречи да уђу дубље у северни део града и направе масакр. Настао је прави рат. Пуцало се на све стране. Неки рањеници лежали су крвави „на сред“ пута. Сирене за узбуну језиво су испуштале свој звук, а санитетска возила јурила градским улицама превозећи повређене до болничког комплекса. Поред албанских екстремиста из „Три солитера“, на припаднике међународних снага и становнике српске националности ватру су отварали и екстремисти из јужног дела града, из правда градског парка у близини Ибра. Том приликом убијени су Боривоје Спасојевић (рођен 1941. године) и Јана Тучев (рођена 1968. године). У каснијим поподневним часовима нереди у северном делу Косовске Митровице су се смирили, док су у јужном делу града веће групе албанских екстремиста наставиле да размењују појединачну ватру са припадницима УН- 
МИК-а и КФОР-а. Биланс седамнаестомартовског сукоба у Косовској Митровици био је стравичан - седморо мртвих и неколико десетина рањених (https://www. youtube.com/watch?v=L87WAGJD3Gg, приступљено 26. 11. 2017. године у 14:37 h; https://www.youtube.com/ watch?v=xqFOML49p-M, приступљено 26. 11. 2017. године у 14:37 h, приступљено 26. 11. 2017. године у 14:47 h; http://www.b92.net/specijal/kosovo2004/, приступљено 26. 11. 2017. године у 15:30 h).

Три дана мартовског погрома дубоко су се урезала у колективно памћење становника Косовске Митровице, као и преосталих косовско-метохијских Срба. То трауматично искуство је трајно нарушило ионако лоше српско-албанске односе. Обале Ибра биле су удаљеније него икад. Косовска Митровица је дефинитивно (п)остала подељени град. Један град, а два (паралелна) света.

И поред формалног завршетка ратних сукоба, о овом ареалу није било могуће говорити као о „постконфликтном подручју“ већ више подручју сукоба нижег интензитета. Ту, дакле, граница између „конфликтног“ и „постконфликтног“ није била довољно јасна, одакле је потекла поприлично неизвесна и сива свакодневица „обичног“ становника, са недефинисаним институционално-правним статусом, крајње непредвидивом будућношћу, животом у готово потпуној конфузији, без икакве шансе за неким дугорочним планирањем. Живот се сводио по оној народној, „од данас до сутра“, са надом да се „претекне“.

Али, и поред свега тога, поред нимало светле прогнозе за будућност, Срби у Косовској Митровици су опстали. За то је свакако најзаслужнија њихова вишегодишња борба, пожртвовање, инат, упорност и истрајност, али и још један врло битан фактор - сигурна „позадина“. Наиме, северни део Косовске Митровице 
се природно, географски ослања на општину Звечан у којој живи преко 95\% Срба. ${ }^{5}$ Звечан се, даље, наслања на општине Зубин Поток и Лепосавић у којима такође живе Срби у највећем проценту, тако да су они на северу Косова сачували компактност и повезаност са остатком Србије. Захваљујући томе, српски државни органи су и после 1999. године успели да сачувају велики економски, политички и културни утицај на Косовску Митровицу, као једину српску урбану (полу) целину на Косову и Метохији, а преко ње посредно и на све остале српске средине на овом простору.

Осим одржавања платног промета, увођења тзв. „косовског додатка“ и помагања на разне начине, једна од најзначајнијих мера охрабрења за преостали српски живаљ била је одлука Владе Србије крајем 2001. године о премештању највећег броја факултета избеглог Приштинског универзитета у Косовску Митровицу (Службени гласник Републике Србије бр. 60/01). У овај град су измештени Филозофски, Правни, Економски, Медицински, Природно-математички и Факултет техничких наука. Остали факултети Пу премештени су у друге варошице северног дела Косова и Метохије: Учитељски и Факултет за спорт и физичко васпитање у Лепосавић, Пољопривредни у Лешак, а Факултет уметности у Звечан. Прилив младих људи и интелигенције коју је са собом донео Универзитет улио је нову енергију и наду у опстанак. Оживели су кафићи, пабови, рок клубови и дискотеке у којима се традиционално окупља млади свет. Повратак Универзитета у

5 Општину Звечан, поред самог урбаног насеља, чини још 35 села. Према подацима ОЕБС-а, укупан број становника процењен је на око 16.650 , а Албанаца свега 350, насељених у три села (Бољетин, Жажа и Липа). - Zvečan/Zvecan Municipal profile, OSCE, November 2011, http://www.osce.org/kosovo/13136 
Приштини на ове просторе представљао је вероватно најснажнији импулс борби за опстанак српског живља на Косову и Метохији. То је, уз локалну самоуправу, школство и здравство, институција без које би живот у Косовској Митровици био практично незамислив. На овој високошколској образовној установи студира више од 10.000 младих академских грађана, углавном са Косова и Метохије, али и централне Србије и Црне Горе. Њихово присуство учинило је да Косовска Митровица постане град младих људи, пуних елана и позитивне енергије. То је улило нову наду Митровчанима да могу опстати у свом граду и поред свих неповољних околности које су их окруживале.

Поред универзитета, у Косовској Митровици, али и другим српским срединама на Косову и Метохији, са својим радом су наставиле и друге установе чији је оснивач и финансијер била Република Србија. Локална самоуправа, школство, здравство, судство, сектор за културу, служба социјалне заштите, Национална служба за запошљавање, одељења МУП-а за издавање личних докумената и возачких дозвола и друге институције наставиле су са својом делатношћу. То је локалном становништву стварало какав-такав осећај сигурности и припадности својој држави, упркос њеном окрњеном суверенитету. Ипак, поменуте институције су за косовске Албанце и међународну заједницу представљале „паралелне структуре“, које је требало расформирати, чему су се Срби снажно противили. Разлози за такав став су и више него јасни: где год није било српских институција, где год су оне гашене или повучене, доживљавали су егзодус. Чињеница да се на нешто више

6 Paralelne strukture na Kosovu 2006-2007, OSCE, http://www.osce. org/sr/kosovo/24620? download=true 
од 50 километара северно налази административна линија централне Србије, давала је Митровчанима у северном делу града сигурност, а јавна или прећутна подршка званичног Београда уверење да држава стоји иза њих. Борба за опстанак својих институција чинила је саставни, незаобилазни део борбе за преживљавање косовско-метохијских Срба. Она је, чини се, била успешна, све до потписивања Бриселског споразума 19. априла 2013. године, којим се, практично, укидају неке врло важне институције Републике Србије на овом простору. Њима је била намењена интеграција у институционално-правни систем тзв. „Републике Косово“7

7 То се, пре свега односи на безбедносне структуре и судство, који су дотад функционисали по законима Републике Србије. По тачкама 7, 8, 9 и 10. Бриселског споразума ове институције се практично утапају у тзв. „косовски систем“. Цитирамо: „7. На Косову ће постојати јединствене полицијске снаге које се зову Косовска полиција. Сва полиција на северу Косова ће бити интегрисана у оквир Косовске полиције. Плате ће исплаћивати само Косовска полиција. 8. Члановима других српских безбедносних структура биће понуђена места у еквивалентним косовским структурама. 9. Постојаће регионални командант полиције за четири општине на северу у којима Срби чине већинско становништво (северна Митровица, Звечан, Зубин Поток и Лепосавић). Командант овог региона биће косовски Србин кога именује Министарство унутрашњих послова са списка који достављају четири градоначелника у име Заједнице/Асоцијације. Састав КП на северу ће одсликавати етнички састав становништва ове четири општине. (Постојаће још један регионални командант полиције за општине јужна Митровица, Србица и Вучитрн). Регионални командант четири северне општине ће сарађивати са другим регионалним командантима. 10. Судске власти биће интегрисане и функционисаће у оквиру правног система Косова. Апелациони суд у Приштини ће успоставити веће које ће бити састављено од већине судија косовских Срба, које ће бити надлежно за све општине у којима су Срби већинско 
Највећи број Срба на овом подручју поменути споразум и његове одредбе није дочекао са одобравањем. Свако ко је тих дана био у северном делу Косовске Митровице, Звечану, Зубином Потоку или било ком другом месту на северу Косова јасно је могао да види и осети дубоко неслагање локалног становништва са оним што је потписано у Бриселу. ${ }^{8}$ Оним што је кројило њихове

становништво. Одељење Апелационог суда, кога чине административно особље и судије, имаће сталну канцеларију у северној Митровици (Окружни суд у Митровици). Свако веће споменутог Одељења ће бити састављено од већина судија косовских Срба. У зависности од природе случаја о коме је реч, веће ће чинити одговарајуће судије." - Бриселски споразум: Први споразум о принципима који регулишу нормализацију односа, http://www.srbija.gov.rs/vesti/specijal. php?id=283757 приступљено 27. 11. 2017. године у 11:23 h. Треба рећи да овим споразумом није прецизирано шта ће бити са школством и здравством на Косову и Метохији који функционишу у оквиру система Републике Србије, што ствара плодне тле за разна тумачења, нагађања и спекулације. - Прим. аут.

8 Према истраживањима која су спроведена међу студентском популацијом, на питање „Какав је Ваш став о 'Бриселском споразуму'?“, најчешће бирани одговор је „То је историјска грешка и 'продаја' српства на Косову и Метохији“ (39,4\%). За њим следи одговор „Реч је о типичном изразу политике наметања решења које Запад спроводи руководећи се властитим интересима" $(29,6 \%)$. Петина испитаника сматра да је реч о нужном уступку који је Србија учинила због приступања ЕУ, а само 8\% „Бриселски споразум“ перципира као „реалност и најбоље што су српски преговарачи могли да издејствују“. Такође, понуђена тврдња „Треба доследно радити на примени 'Бриселског споразума““ добила је 62,7\% негативних одговора. Потпуно сагласних с опцијом доследног рада на примени „Бриселског споразума“ је тек $4,2 \%$, а делимично $3,9 \%$. Висок проценат неодлучних у вези са Бриселским споразумом, 29\%, не изненађује када се има у виду да овај споразум прате бројне непознанице, нејасноће и контроверзе, да се базира на уопштеним формулацијама које су подложне различитим тумачењима и да се декларативно њиме не решава питање статуса, које је за обе стране свакако најважније. - Краговић 2016: 98. 
животе, а за шта их нико није питао. Одлуке скупштина општина да споразум не прихвате, велики протести, прогласи и одласци у Београд нису били од користи. ${ }^{9}$ Отпор Срба са севера Косова и Метохије после одређеног времена био је разводњен и угушен. Приморани су да прихвате „нову реалност“на терену и наставе даље у новим, чини се, још неповољнијим околностима.

У међувремену, током свих тих година, ваљало је живети. А живот просечног, обичног човека управо су обликовали крупни, драматични догађаји, о којима смо писали. Суочавајући се са најразноврснијим проблемима из области личне и колективне безбедности, просвете, здравства, културе, комуналног система, урбанизма, просторног планирања, електро и водоснабдевања, Митровчани су били приморани да изграде неку врсту свог унутрашњег, аутономног, рекло би се, алтернативног друштвеног система, који би им омогућио елементарно преживљавање у својеврсном вакууму у којем су боравили од 1999. године. Возили су аутомобиле, камионе и аутобусе са разним регистарским таблицама или без њих, отварали самосталне трговачке и занатске радње на локацијама које за то нису предвиђене, користили воду која је често била хемијски и бактериолошки неисправна, мрак разбија-

9 https://www.youtube.com/watch?v=PKKRSd4DKhA, приступљено 27. 11. 2017. године у 12:11 h; https://www.youtube.com/ watch?v=heu41itaj1Q, приступљено 27. 11. 2017. године у 12:15 h; http://www.nspm.rs/kosovo-i-metohija/deklaracija-o-neopozivom-odbijanju-briselskog-sporazuma-beograda-i-pristine. html, приступљено 27. 11. 2017. године у 12:20 h; http://www.novosti.rs/vesti/naslovna/drustvo/aktuelno.290.html\%3A430645-Srbi-sa-severa-Kosova-ne-prihvataju-briselski-sporazum, приступљено 27. 11. 2017. године у 12:23h; http://www.politika.rs/ sr/clanak/255979/Protest-studenata-u-K-Mitrovici-zbog-briselskog-sporazuma, приступљено 27. 11. 2017. године у 12:42h. 
ли свећама и уљаним лампама за време вишечасовних рестрикција струје (углавном зими), куповали млеко и млечне производе од сељака са импровизоване пијаце, много пута сви као један бранили град на мосту, гутали сузавац, примали ударце пендрека и палице, а понекад и куршуме, окретали вола на ражњу у центру града и делили врућу ракију, организовали свирке и рок концерте на отвореном, расправљали се око политике, веселили на славама, крштењима, свадбама, туговали на уништеним или оскрнављеним гробовима својих предака... Покушавали су да живе, колико-толико нормално, иако је такав начин живота био само нека врста његове имитације.

Просторије свих локалних, политичких, културних, уметничких, просветних и спортских институција остале су на јужној страни града: зграда општине, културни центар, храм Светог Саве, зграда гимназије, неколико основних школа, пошта, спортска дворана, позориште, биоскоп, библиотека, музеј, историјски архив, обданиште, велики стадион ФК „Трепча“, најлепши паркови, булевари и улице. У северном делу града од значајнијих објеката остали су само болнички комплекс и зграда суда. Имајући у виду ову чињеницу, јасно је колико је било тешко организовати било какве друштвене активности на пољу било чега што чини радост и пуноћу једног људског живота. Ипак, локалним ентузијастима то није сметало да дају све од себе како би покренули нова друштвена дешавања. Тако је, примера ради, у оближњем Звечану током 2003. године основано удружење музичара Косова и Метохије „Унија М“, које је, заједно са групом пријатеља, бивших чланова и симпатизера старог биг-бенда из северног дела подељеног града, покренуло „North City Jazz \& Blues Festival“. Висок уметнички ниво програма, вели- 
ко интересовање публике и изненађујуће добра организација сврстале су „North City“ међу најзначајније културне догађаје овог типа, не само у Косовској Митровици, него и у Србији и околним земљама. Страни музичари који су долазили у Косовску Митровицу са зебњом, очекујући ратну зону и некакве полудивљаке, искрено су били одушевљени фестивалом, топлином и срдачношћу којом су дочекани. Фестивал се одржавао у Дому културе у Звечану и медијски је пропраћен од стране свих великих медијских кућа у Србији, а „Радио Косовска Митровица“ је директно преносио све концерте. До сада је одржано укупно 15 косовско-митровачких фестивала, на којима су наступала врло значајна имена домаће, европске и светске џез и блуз сцене. Публика је, између осталих, имала прилику да чује Васила Хаџиманова, квинтет руба на челу са Мимом Митровићем, Влатка Стефановског, Јована Маљоковића, Ратка Дивјака, Стјепка Гута, Слободана Тркуљу, Рамба Амадеуса, Леб и Сол, Дел Арно бенд, Биг Бенд PTC-a, Фиеста Латина, Аквана Роена из Холандије, Вита Ђордана из Италије, Ињакија Сандовала из Шпаније, Лерија Карлтона из САД, Хуана Гарсију-Херероса из Колумбије, Blues Wire из Грчке, Кубизмо из Хрватске... (http://www.northcityfest.org/Istorija Festivala.html, приступљено 27. 11. 2017. године у 17:37h). Поменути фестивал је, захваљујући свом квалитету, али пре свега самопрегору његових организатора, постао прави бренд Косовске Митровице, надалеко позната манифестација, који је многима променила слику овог града и његових становника.

Поред ове значајне музичке манифестације, од октобра 2007. године у Косовској Митровици се традиционално одржава „бајк-рок мировна мисија“, у коме, осим више хиљада бајкера из целе Србије, регио- 
на и Европе, учествују највећа имена домаће рокенрол сцене. То је повод за долазак мноштва младих у овај град, не само са Косова и Метохије, већ из из Рашке, Краљева, али и других места централне Србије (http:// www.rts.rs/page/stories/sr/story/125/drustvo/2364801/ jubilarna-deseta-bajk-rok-misija-u-kosovskoj-mitrovici. $\underline{\mathrm{html}}$ приступљено 27. 11. 2017. године у 18:12 h). На тај начин је Косовска Митровица постала значајна тачка на концертној рок мапи Србије.

После 18 година паузе, 2011. године обновљен је Сабор културно-уметничког стваралаштва Сpбије. Када је јуна 2011. године поводом Видовдана одржан 17. (обновљени) Сабор, грађани нису крили своје одушевљење програмом. Десет дана у Косовској Митровици су се дружили и приказивали своје уметничко умеће сликари, песници, глумци, фолклорни уметници и музичари из Србије, Црне Горе, Републике Српске и БJР Македоније (https://kckm.org/saborkulturnoumetnickog-stvaralastva-srbije-vracen-na-scenu/, приступљено 27. 11. 2017. године у 18:46 h). Ова манифестација се од тада одржава сваке године.

У Косовској Митровици је од 2005. до 2014. године била смештена и Српска драма приштинског Народног позоришта, чија се сцена налазила у Дому културе у Звечану. Својој старој публици Српска драма се вратила представом „Џика из Џигољ“ Ивана Ивановића. Од тада до данас настало је преко двадесет нових представа (http://pristina.theater/, приступљено 27. 11. 2017. године у 19:17 h). Неадекватни услови за рад натерали су поменути театар да лута од Лепосавића, преко Звечана и Косовске Митровице, до Грачанице, где се коначно скрасио.

Један од битних аспеката митровачке свакодневице јесте њен духовни живот и одређене конфесио- 
налне специфичности. Једини православни храм у граду остао је на јужној страни града, а како Срба тамо више није било, осетила се насушна потреба за подизањем новог, у северном делу. Већ током јануара 2001. године формиран је Одбор за изградњу храма Светог Димитрија (Сташић 2016: 8). Одређена је и локација за изградњу цркве - брдо Кукавица, изнад самог града. То место је тадашњи епископ рашко-призренски Артемије током марта 2001. године благословио и освештао, што је означило почетак процеса израдње овога храма (Исто: 8). Нацрт пројекта нове цркве израдио је тим ДП „Урбанизам“ из Косовске Митровице. Током августа 2001. године упућен је апел грађанима да добровољним прилозима помогну изградњу цркве. Међутим, у саму реализацију изградње није се могло ући због противљења администратора „УНМИК општине Митровица“ Џона Роџерса. Зато је тек две године касније, уз велике напоре, 14. септембра 2003. године постављен и освештан њен камен темељац. После надгорњавања са странцима и великог противљења комшија са друге стране моста, црква се полако дизала. Финансирање њене изграње помагале су практично све српске установе у Косовској Митровици и њихови радници: локална самоуправа, општински суд, окружни судови и тужилаштва, здравствени центар, РМХК „Трепча“, Универзитет у Приштини са привременим седиштем у Косовској Митровици, Управа прихода, Југобанка, Комерцијална банка, Ауто-мото савез, Електрокосмет, Пошта, Телеком, Координациони центар за Косово и Метохију... Поред њих, у акцију изградње новог косовскомитровачког храма укључиле су се и општине Звечан, Зубин Поток, Лепосавић, локални привредници, самосталне трговачке и угоститељске радње... Једном речју, сви који су били у могућности (Исто: 35$)$. У 
међувремену, Одбор за изградњу храма Светог Димитрија преузео је на себе обавезу организације прославе градске славе, Митровдана. Од 2003. године организују се литије поводом градског крсног имена и богат културно-уметнички програм. Од 6. јануара 2004. године организује се и налагање бадњака код храма Светог Димитрија. Ове две јавне манифестације су, иначе, у међувремену постале симболички врло важне за духовни живот становника северног дела града. Оне у себи носе препознатљивост индивидуалне и колективне идентификације са православном верском традицијом. Њихова симболика се, исто тако, огледала и на пољу етничке (само)идентификације. Учествовањем у митровданским литијама и јавним паљењима бадњака Митровчани су оснаживали осећај унутаргрупне повезаности и заједништва. То је, на неки начин, представљало и слику својеврсне друштвене мобилизације српског становништва северне Косовске Митровице, у циљу чувања и промовисања свог националног идентитета (Павловић 2012: 217-228).

У међувремену, у Мартовском погрому је девастиран храм Светог Саве у јужном делу града. Црква је спаљена и похарана, а иконе уништене или оскрнављене. Све наочиглед војника КФОР-а, који су уништавање косовскомитровачке градске цркве немо посматрали, без икакве жеље да је заштите. То је, природно, свим православним хришћанима у северном делу града јако тешко пало, ${ }^{10}$ али им је дало додатну снагу и мотив да

10 Карактеристична је јако потресна сцена обележавања Васкрса 2004. године у спаљеном храму Светог Саве у јужном делу града. Чланови црквеног хора „Бранислав Нушић“ под управом Петра Ракића су заједно са малобројним верницима ушли у спаљену цркву, појући тропар у славу васкрсења Господњег. Док су спаљеним светосавским храмом одјекивали звонки гла- 
наставе са изградњом новог храма Светог Димитрија. Двадесет четвртог јула 2005. године освештани су и постављени крстови на куполама цркве, а 4. октобра исте године одјекнула су и звона на новом звонику покрај светодимитровског храма (Сташић 2016: 66, 71). Први пут након шест година Косовском Митровицом су звонила православна звона и позивала вернике на окуп и слогу. Осмог новембра 2005. године, на Митровдан, блаженопочивши патријарх српски Павле освештао је новоизграђени храм Светог Димитрија, уз саслужење више архијереја, свештеника и монаха и присуство више хиљада верника (Исто: 74-75). Од тада, до дана данашњег, то је једно од најзначајнијих места у северној Косовској Митровици. То није само црква - то је градски оријентир, омиљено место за окупљање, налажење, шетање, разговарање, уживање у сунчаним данима, посматрање панораме... Објекат који је постао један од симбола овог града.

Интересантно је приметити да су један од најупечатљивијих и најбизарнијих симбола „два света“ Косовске Митровице - гробља. Игром судбине, после ратних збивања 1999. године, на јужној страни остало је православно, а на северној муслиманско гробље. Православно гробље је старо преко 100 година. До 1886. године, са јужне стране локације где се данас налази храм Светог Саве постојало је православно гробље, да би након почетка градње поменутог храма оно било дис-

сови и стихови „Христос воскресе из мертвих, смертију смерт поправ, и сушчим во гробје живот даровав“, низ лица свих присутних сливале су се сузе. Истовремено су певали и плакали. То је била слика која је обишла свет. - Снимак те сцене може се видети путем следећег линка - https://www.youtube. com/watch?v=ZZF1rB12Axs, од 10:42 до 11:43. Приступљено 28. 11. 2017. године у 15:52 h. 
лоцирано преко реке Ситнице на место где се и данас налази. Званичан почетак сахрањивања православних хришћана на ово гробље датира 1913. године, где су се сахрањивали све до лета 1999. године (Пантовић 1996: 56). Од тада, па све до дан-данас, православни хришћани из Косовске Митровице и Звечана се сахрањују у Рудару, које је пре тога било обично сеоско гробље. ${ }^{11}$ Гробље у јужном делу Косовске Митровице доживело је трагичну судбину, попут многих других српских меморијалних обележја на Косову и Метохији. После

11 Иначе, место Рударе је широј јавности постало познато током јула 2011. године, после покушаја специјалних косовско-албанских снага ROSU да насилно заузму административне прелазе Јариње и Брњак. Срби су управо у овом месту подигли велику барикаду на самом магистралном путу Приштина-Рашка, покушавајући да спрече њихово заузимање северног дела Косова и Метохије. Тако је настала једна од најжешћих послератних криза на Косову и Метохији, која је, на крају, резултирала тзв. „Борковим споразумима“ о интегрисаним прелазима, после којег су барикаде постепено уклањане. За време ове кризе догодило се низ инцидената у којима је лакше или теже повређено неколико стотина људи. Једна од крајњих консеквенци ове кризе био је Бриселски споразум, о којем је било више речи на претходним страницама. На месту где је некада постојала велика барикада од шљунка, песка, шута, цигала и другог материјала, данас стоји велики крст, као својеврсни знамен ових драматичних догађаја. Више о барикадама у Рудару види у: https://www.youtube. com/watch?v=SUITCZ-7r0M, приступљено 28. 11. 2017. године у 16:42 h; https://www.youtube.com/watch?v=jNXl30jdfME, приступљено 28. 11. 2017. године у 16:56 h; https://www.youtube.com/ watch? $\mathrm{v}=3 \mathrm{Nrm} 5 \mathrm{v}$ UKOI\&t=87s, приступљено 28. 11. 2017. године у 17:13 h; https://www.youtube.com/watch?v=SKIGO8F8CtE, приступљено 28. 11. 2017. године у 17:24 h; https://www.youtube. com/watch?v=z2zqqGNKWCc, приступљено 28. 11. 2017. године y 17:30h; https://www.youtube.com/watch?v=S3WVUgZ6vxw, приступљено 28. 11. 2017. године у 17:41h; https://www.youtube.com/ watch?v=-7AJ4IfMSWU, приступљено 28. 11. 2017. године у 17:49 h; https://www.youtube.com/watch?v=3ZOYv212m3M\&t=134s, приступљено 28. 11. 2017. године у 17:56 h; 
1999. године оно је постало предметом вандализма каквог нема нигде у савременој Европи. Капела на гробљу је спаљена (једно време је служила као штала и јавни нужник), а сами надробни споменици систематски уништавани и скрнављени. Проценат девастације православних спомен-обележја на овом гробљу је преко 70 \%. Срби га посећују искључиво на Задушнице, и то организовано, у пратњи КФОР-а. ${ }^{12}$

За разлику од православног, муслиманско гробље у северном делу Косовске Митровице није било на мети разних вандала и екстремиста. Налази се са обе стране магистралног пута Косовска Митровица - Рашка. Испод пута, ка реци Ибар, лоцирано је муслиманско гробље старијег датума, које се више не користи за сахрањивање покојника. Изнад пута налази се новије муслиманско гробље на којима се покојници исламске вероисповести најчешће сахрањују после периода Другог светског рата. Спомен-обележја на овом гробљу су недирнута. Ниједан споменик није срушен или оскрнављен. Трава се редовно коси и плеви од корова. На овом месту се и дан-данас сахрањују муслимани из северног дела Косовске Митровице и Звечана. Слободно га посећују за време својих верских празника.

Упркос томе, многи Албанци и странци, (мас-медији су „посебна прича“) врло често прећуткују ове чињенице, желећи да Србе увек представе као непоправљиве „лоше момке“, неспособне за миран, норма-

12 О личним утисцима, сећањима и осећањима аутора овог рада везаних за посете гробљу у јужном делу града можете сазнати више путем линка - http://jadovno.com/zadusnice-na-oskrnavljenom-groblju/\#.WlZ-JLynHcs, приступљено 28. 11. 2017. године у 18:24 h; Напомена: на почетку текста постоји грешка у наведеном датуму. Уместо да пише четрнаести ФЕБРУАР 2015. године, стоји четрнаести новембар (sic!') 2015. године. 
лан суживот, „поштовање различитости“ и толеранцију, и поред живих доказа да то једноставно - није тачно. У прилог томе говори и то што Албанци, Турци, Бошњаци, Роми и други припадници несрпских заједница у северном делу Косовске Митровице живе исто као и Срби. Прави пример за то је Бошњачка махала, мултиетнички и мултиконфесионални кварт, смештен уз Ибар између главног и „Источног“ моста. Све до краја шездесетих година прошлог века, у овој четврти су углавном живели Муслимани (од 1993. године Бошњаци) и Срби, уз неколико турских породица. Албанаца скоро да није било. Албанци се у Бошњачку махалу, у већем броју насељавају седамдесетих и осамдесетих година прошлог века. И поред исељавања српског становништва у касним седамдесетим и осамдесетим годинама, у Бошњачкој махали је до последњег рата живело око 100 српских породица, док су се муслиманске породице у већем броју исељавале током деведесетих година прошлога века, укључујући и период после '99 (https://www.balcanicaucaso.org/bhs/ zone/Kosovo/Bosnjacka-mahala-zivot-uz-Ibar-44586, приступљено 28. 11. 2017. године у 19: 11 h). После ратних сукоба, посебно током 1999. и 2000. године ово насеље је постало поприште бројних међунационалних инцидената. Становници северне Косовске Митровице и данас имају горка сећања на међународни покушај успостављања такозваних „зона поверења“ (делови града у којима би се населили Албанци, чему су се Срби снажно противили). ${ }^{13}$ Приликом успостављања једне

13 Приликом успостављања „зоне поверења“ у Бошњачкој махали, од преко 90 српских породица остало је свега осам, а у насељу „Три солитера“ од око 60 српских домаћинстава, остало је - пет. То је био јасан показатељ Србима у северном делу Косовске Митровице шта их чека ако дозволе да се „зоне поверења“ 
од ових зона у Бошњачкој махали, односно покушаја проширивања ове зоне дубље у српске делове града, у тадашњим вишедневним сукобима између локалног становништва и француских војника, поред повређених на обе стране, ампутирани су делови ногу једној жени и мушкарцу услед повреда насталих од испаљивања шок бомби (Исто, https://www.balcanicaucaso.org/ bhs/zone/Kosovo/Bosnjacka-mahala-zivot-uz-Ibar-44586). Одлучан отпор Срба је приморао припаднике међународних снага да одустану од свог плана и уклоне „зоне поверења" које су покушали да успоставе. Након тога, ситуација се мало по мало стабилизовала. Протоком времена, поправили су се односи између комшија раличитих вера и нација. Албанци су отворили бројне трговачке, занатске и угоститељске објекте. Због разне мешовите робе (углавном одеће, обуће, кућних потрепштина, мобилних, рачунарских и те-ве уређаја) и изразито ниских цена, њихове радње постале су најпопуларније место за шопинг становника северног дела града. Бошњачка махала је захваљујући томе постала права „трговачка Мека“, место које спаја Србе и Албанце (http:// kossev.info/strana/arhiva/bosnjacka mahala spaja srbe i albance u mitrovici /5702, приступљено 28. 11. 2017. године у 19: 34 h). Поред Бошњачке махале, у којој заједно живе Срби, Албанци, Турци, Бошњаци, Горанци, Роми и други, слична је ситуација у друга два мултиетничка кварта, Микронасељу и „Три солитера“ (у Микронасељу Албанци имају и своју основну школу, а код „Три солитера“ налази се пешачки мост који их директно спаја са јужним делом града). Ништа, наравно, ово не би било необично (напротив), да нема чињенице која каже да у

прошире и на друге делове града. - http://arhiva.glas-javnosti.rs/ arhiva/2001/04/03/srpski/P01040204.shtml, приступљено 28. 11. 2017. године у 19: $22 \mathrm{~h}$. 
јужном делу Косовске Митровице, сем свештеника са породицом, не живи ниједан једини Србин.

Међуљудски, комшијски односи између становника северног дела града могу се углавном описати као коректни, релативно солидарни (посебно у неким тешким моментима), али не и онакви какви су били „пре рата“, барем по сведочењу многих Митровчана. И заиста, утисак је да су ратна дешавања јако утицала на развој односа међу комшијама у овом граду. Често је присутно поређење комшијских односа некада и сад, при чему се на комшијске односе из времена њиховог детињства или младости скоро увек гледа са дозом носталгије, уз навођење да су они тада били далеко бољи, приснији и распрострањенији него што је то случај данас (Павловић 2013: 258). Ту се превасходно мисли на односе са комшијама Србима, будући да се на односе исте врсте са припадницима других етничких заједница, пре свега са Албанцима, гледа као на односе који услед извесних културолошких разлика ни пре рата нису били претерано блиски (иако је, свакако, било таквих случајева). Услед демографских промена, прилива нових људи из разних делова Косова и Метохије, безбедносних, друштвено-политичких и економских изазова, они су се осетно променили. Старији говоре да се некада врата од куће или стана нису закључавала, што данас свакако није случај. Комшилуку се, готово по правилу, приписује посебан значај, утолико више што се под њим подразумева круг људи у чијој се непосредној близини живи и са којима се, заправо, одређени животни простор дели. Оно што се у том смислу на првом месту наглашава јесу добри односи који се са комшијама имају, или, боље речено, добри односи које са комшијама треба имати. Под добрим односима сматра се пристојност и добронамерност у комуникацији приликом свакодневног сусретања 
на степеништу или на улазу у зграду, уколико је реч о заједничком стамбеном објекту, али и гостољубивост и међусобно посећивање (Исто: 263).

Један од највећих проблема у северном делу Косовске Митровице је незапосленост, слично као и у остатку Србије. Према званичним подацима Националне службе за запошљавање у овом граду је током августа 2012. године било 1.670 незапослених лица (Незапослена лица у месецу августу 2012. године, општина Косовска Митровица, НЗС, Република Србија, Округ Косовско-митровачки). Међу њима је незанемарљив проценат младих, високообразованих људи, који најчешће због тога желе да оду из ове средине. На целом подручју северног дела Косова и Метохије у том моменту било је преко 5.500 незапослених, претпоставља се да је у међувремену тај број засигурно осетно порастао. Да би обезбедили основе своје егзистенције, људи прибегавају разним другим пословима, обично онима који немају никакве везе са њиховим основним занимањима. Неретки су случајеви да дипломирани инжињер електротехнике ради као таксиста, професор енглеског језика као конобар, лекар као пијачни продавац, па и дипломирани биолог као радник у градској чистоћи (http://www.radiokontaktplus.org/sport/mitrovica-slavisasa-metlom-u-ruci-i-diplomom-u-dzepu-video-foto/12246, 29. 11. 2017. године у 13: 21 h). Као и свуда где влада оваква ситуација људи једноставно раде све што могу само да преживе. Преживљаване је можда и кључна реч целе ове приче. Реч која најбоље описује прилике у овом граду и битисање његових становника.

Пре извесног времена аутор овог текста је држао предавање на тему развоја Косовске Митровице у 20. 
веку. У публици су, између осталих, били присутни гимназијалци рођени 1999. године. Током дела излагања моје маленкости о неким знаменитим градским објектима као што су хотел „Јадран“, биоскоп „Тесла“ или црква Светог Саве гледали су ме помало чудно, као да им говорим о нечем крајње непознатом и далеком, а не њиховом родном месту. Морао сам им презентовати фотографије објеката о којима сам причао. Нису знали како изгледају неке најстарије и најпознатије локације њиховог завичаја. Нису ни могли знати. Они их и не памте. А и како су могли...? У години њиховог рођења, ове грађевине су остале с друге стране моста. C „оне стране“ паралелног света. А шта су запамтили? Tj. шта су могли запамтити? Једино (после)ратне сукобе, безбројне инциденте, рестрикције струје и воде, епидемије заразне жутице, свињског грипа и малих богиња, оскрнављене гробове својих предака, разроване улице, барикаде, вечиту борбу њихових родитеља, рођака и комшија за егзистенцију, голи живот... Уз неке мале, ситне, животне радости: укусне колаче уз бозу и лимунаду у „Шару“, „Лондону“ или „Пеливану“, вруће буреке у „Бистрици“, „Палми“ или „Вожду“, прве љубави у школским двориштима у којима су налазили гелеpe, позоришне представе испред барикада, прве баскет мечеве на импровизованом кошаркашком терену у близини зграде СУП-а коју су уништили НАТО бомбардери, прве пољупце испод кестена код старе школе „Бранко Радичевић“ у којој су смештене српске избеглице из Крајине... Мало је.

А то више и нису деца. Имају по 18-19 година. То су одрасли, пунолетни људи. Читава једна генерација која цео свој живот живи у некој врсти (полу)ванредног стања. Она која се успављивала уз рафале и будила уз сирене за узбуну. Она која не памти неко лепо, срећно, „нормално“ време. Она која никада није прешла 
мост. Она чија прва асоцијација на мост није Андрићева ћуприја - већ управо њихов непређени ибарски мост који им је одредио судбину. То је њихов живот. Свакодневна, сурова, тешка борба за опстанак. Вера да ће се нешто променити на боље, чак и онда када за то нема реалних изгледа. Нада да ће дочекати неке ведрије дане. Љубав према прљавим улицама са којих још није нестао опор мирис усирене крви свих оних који су је дали да би њима слободно шетали. То је оно што нас држи. То је живот свих нас који смо, упркос свему, остали Митровчани. Јер, одавде нема назад.

\section{Извори и литература}

Извори

\section{Необјавтени извори}

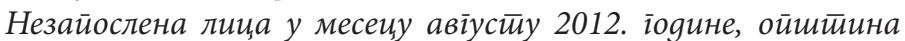
Косовска Митировица, Национална служба за запошљавање, Република Србија, Округ Косовско-митровачки

\section{Објављени извори}

Службени гласник Републике Србије

\section{Интернет извори}

Bošnjačka mahala spaja Srbe i Albance u Mitrovici, http:// kossev.info/strana/arhiva/bosnjacka mahala spaja srbe i albance u mitrovici /5702, приступљено 28. 11. 2017. године у 19: $34 \mathrm{~h}$.

Bošnjačka mahala, život uz Ibar, https://www.balcanicaucaso.org/ bhs/zone/Kosovo/Bosnjacka-mahala-zivot-uz-Ibar-44586, приступљено 28. 11. 2017. године у 19: $11 \mathrm{~h}$.

Бриселски споразум - Влада Републике Србије, http://www. srbija.gov.rs/vesti/specijal.php?id=283757 приступљено 27. 11. 2017. године у 11:23 h. 
Декларација о неопозивом одбијању бриселског споразума Београда и Приштине, http://www.nspm.rs/kosovo-imetohija/deklaracija-o-neopozivom-odbijanju-briselskogsporazuma-beograda-i-pristine.html, приступљено 27. 11. 2017. године у 12:20 h.

Demo, https://www.youtube.com/watch?v=U4Su-g4Q4H0, приступљено 26. 11. 2017. године у 13:36 h.

DOKUMENTARNI FILM 17 mart 2004 "Da se ne zaboravi" 201612 godina posle, https://www.youtube.com/ watch?v=ZZF1rB12Axs, од 10:42 до 11:43. Приступљено 28. 11. 2017. године у 15:52 h.

Ekskluzivno - Kosovska Mitrovica - 17. mart 2004. godine, https://www.youtube.com/watch?v=xqFOML49p-M, приступљено 26. 11. 2017. године у 14:37 h.

Задушнице на оскрнављеном гробљу, http://jadovno.com/ zadusnice-na-oskrnavljenom-groblju/\#.WlZ-JLynHcs, приступљено 28. 11. 2017. године у 18:24 h.

Zapaljen granični prelaz Jarinje, https://www.youtube.com/ watch?v=z2zqqGNKWCc, приступљено 28. 11. 2017. године у 17:30 h.

Zvečan/Zvecan Municipal profile, OSCE, November 2011, http:// www.osce.org/kosovo/13136, 26. 11. 2017. године у 18:22 h.

Istorija NORTHCITY jazz\&Blues Festivala, http://www. northcityfest.org/Istorija Festivala.html, приступљено 27. 11. 2017. године у $17: 37 \mathrm{~h}$.

Jubilarna deseta "Bajk rok misija" u Kosovskoj Mitrovici, http:// www.rts.rs/page/stories/sr/story/125/drustvo/2364801/ jubilarna-deseta-bajk-rok-misija-u-kosovskoj-mitrovici. html приступљено 27. 11. 2017. године у 18:12 h.

KOSOVO: K-FOR TROOPS BLOCK ETHNIC ALBANIAN MARCH UPDATE

https://www.youtube.com/watch?v=5kQXEG2rSpk, приступљено 25. 11. 2017. године у 20: $42 \mathrm{~h}$.

KOSOVO: MITROVICA: GRENADE ATTACK WRAP https:// www.youtube.com/watch?v=uzJYRFQByEs, приступљено 25. 11. 2017. године у 20: $49 \mathrm{~h}$.

KOSOVO: MITROVICA: NATO TAKES CONTROL OF IBAR BRIDGE https://www.youtube.com/watch?v=FlTeiFCN7dc, 
приступљено 25. 11. 2017. године у 20: 57 h.

KOSOVO: MITROVICA: VIOLENCE CONTINUES https:// www.youtube.com/watch?v=W6L4wb22vAo, приступљено 25. 11. 2017. године у 21: $43 \mathrm{~h}$.

KFOR: U Kosovskoj Mitrovici ubijeno troje, ranjeno dvadeset pet osoba, B92, https://www.b92.net/info/vesti/index. php? yуyу $=2000 \& m m=02 \& d d=04 \& n a v i d=4386$, приступљено 26. 11. 2017. године у 12:23 h.

Kfor se povukao iz Rudara, https://www.youtube.com/ watch?v=jNXl30jdfME, приступљено 28. 11. 2017. године y $16: 56 \mathrm{~h}$.

KFOR počeo da uklanja barikade, https://www.youtube.com/ watch?v=3ZOYv212m3M\&t=134s, приступљено 28. 11. 2017. године у 17:56 h.

Mitrovicë/Mitrovica Municipal Profile, OSCE, November 2011 http://www.osce.org/kosovo/38678 , приступљено 12. 12. 2012. године у 20: $25 \mathrm{~h}$

Mitrovic 7 Korrik 1999, https://www.youtube.com/ watch?v=PisnzsOQbIw, приступљено 25. 11. 2017. године y 20: $25 \mathrm{~h}$;

Mitrovice 1999 - Marshi i shqiptareve ne pjesen veriore

https://www.youtube.com/watch?v=5tfMFhFiLMc\&t=11s, приступљено 25. 11. 2017. године у 22:33 h.

Mitrovica: Diploma počistila metlu! (VIDEO, FOTO), http:// www.radiokontaktplus.org/sport/mitrovica-slavisa-sametlom-u-ruci-i-diplomom-u-dzepu-video-foto/12246, 29. 11. 2017. године у 13: $21 \mathrm{~h}$.

Народно позориште Приштина - Историјат, http://pristina. theater/, приступљено 27. 11. 2017. године у 19:17 h.

$\mathrm{Na}$ severu Kosova mirno, blokade pojačane, https://www. youtube.com/watch?v=SKIGO8F8CtE, приступљено 28. 11. 2017. године у 17:24 h.

Neredi u Kosovskoj Mitrovici (17. Mart 2004),

https://www.youtube.com/watch?v=L87WAGJD3Gg, приступљено 26. 11. 2017. године у 14:37 h.

Noć dugih noževa, NIN, http://www.nin.co.rs/2000-02/10/11513. html, приступљено 26. 11. 2017. године у 12:23 h.

Од 1999. на мосту у Косовској Митровици 118 инци- 
дената, Политика Online, http://www.politika.rs/scc/ clanak/297241/Od-1999-na-mostu-u-Kosovskoj-Mitrovici118-incidenata, приступљено 26. 11. 2017. године у 13:57 h.

Osmi dan krize na severu Kosova, https://www.youtube.com/ watch? $\mathrm{v}=3 \mathrm{Nrm} 5 \mathrm{v}$ UKOI\&t=87s, приступљено 28.11. 2017. године у 17:13 h.

Paralelne strukture na Kosovu 2006-2007, OSCE, http://www. osce.org/sr/kosovo/24620?download=true, 26. 11. 2017. године у 19:41 h.

Протест студената у К. Митровици због бриселског споразума, Политика Online, http://www.politika.rs/sr/ clanak/255979/Protest-studenata-u-K-Mitrovici-zbogbriselskog-sporazuma, приступљено 27. 11. 2017. године у $12: 42 \mathrm{~h}$.

Proširuje se «zona poverenja» u Kosovskoj Mitrovici, http:// arhiva.glas-javnosti.rs/arhiva/2001/04/03/srpski/P01040204. shtml, приступљено 28. 11. 2017. године у 19: $22 \mathrm{~h}$.

Report on the Role of the Media in the March 2004 Events in Kosovo by the OSCE Representative on Freedom of the Media, http://www.osce.org/fom/30265, приступљено 26. 11. 2017. године у 15:10 h.

Рударе, Косово - Барикаде на путу - 29.07.2011, https://www. youtube.com/watch?v=SUITCZ-7r0M, приступљено 28. 11. 2017. године у $16: 42 \mathrm{~h}$.

SABOR KULTURNOUMETNIČKOG STVARALAŠTVA SRBIJE VRAĆEN NA SCENU, https://kckm.org/saborkulturnoumetnickog-stvaralastva-srbije-vracen-na-scenu/, приступљено 27. 11. 2017. године у 18:46 h.

Srbi sa severa: Sporazum neprihvatljiv, https://www.youtube. com/watch?v=PKKRSd4DKhA, приступљено 27. 11. 2017. године у $12: 11 \mathrm{~h}$.

Srbi s Kosova odbili briselski sporazum, najavili proteste, https:// www.youtube.com/watch?v=heu41itaj1Q, приступљено 27. 11. 2017. године у 12:15 h.

Srbi sa severa Kosova ne prihvataju briselski sporazum, http:// www.novosti.rs/vesti/naslovna/drustvo/aktuelno.290. html\%3A430645-Srbi-sa-severa-Kosova-ne-prihvataju- 
briselski-sporazum, приступљено 27. 11. 2017. године у 12:23 h.

Sukob Albanaca i Kfora u Kosovskoj Mitrovici - panika medju Srbima, B92, https://www.b92.net/info/vesti/index.php? yyyy $=2000 \& \mathrm{~mm}=02 \& \mathrm{dd}=21 \&$ nav category $=1 \&$ nav id=4790, приступљено 26. 11. 2017. године у 13:49 h.

SukobKFOR-ailokalnihSrbanasjeveruKosova-AlJazeeraBalkans, https://www.youtube.com/watch?v=S3WVUgZ6vxw, приступљено 28. 11. 2017. године у 17:41h.

Sukob na Jarinju - KFOR troops shooting at unarmed Serb civilians in Kosovo and Metohija, https://www.youtube.com/ watch?v=-7AJ4IfMSWU, приступљено 28. 11. 2017. године y $17: 49 \mathrm{~h}$.

Тринаест година од Мартовског погрома на Косовy, $\quad P T C, \quad$ http://www.rts.rs/page/stories/ci/story/124/ drustvo/2668249/trinaest-godina-od-martovskog-pogromana-kosovu.html, приступљено приступљено 26. 11. 2017. године у $15: 38 \mathrm{~h}$.

Hronologija događaja (16 - 22. mart 2004), B92, http://www.b92. net/specijal/kosovo2004/, приступљено 26. 11. 2017. године у 15:30 h.

\section{Литература}

Vlašković, Zoran, i Lazarević, Tatjana. Kosovska Mitrovica - sever 1999-2005. Kosovska Mitrovica: NVO „Jelena Anžujska“, 2005. Pdf.

Јевтимијевић, Војислав. Северно Косово кроз истиорију gо краја XX века с йосебним освритом на Банску. Београд: Службени гласник, 2008. Штампано.

Краговић, Бранислава. „Ставови студената о могућим решењима за статус Косова и Метохије“. Проф. др Урош Шуваковић - проф. др Јасмина Петровић (ур.). Сйуgeн-

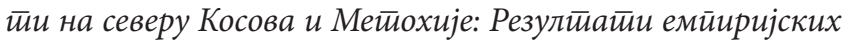
истираживағьа. Косовска Митровица: Филозофски факултет Универзитета у Приштини са привременим седиштем у Косовској Митровици, 2016. 93-111. Штампано. 
Павловић, Александар. „Јавно налагање бадњака у северној Косовској Митровици“. Башӣина, св. 32 (2012): 211-231.

Павловић, Александар. „Комшијски односи међу Србима у северној Косовској Митровици“. Башӣuна, св. 35 (2013): 251-269.

Пантовић, Љубиша. Храм Свет̄о̄ Саве у Косовској Мийровици. Косовска Митровица: Историјски архив; Приштина: Народна и универзитетска библиотека, 1996. Штампано.

Сташић, Нинослав. Храм Свейог̄ Димийрија у Косовској Митеровици. Косовска Митровица: Српска православна црквена општина Косовска Митровица, 2016. Штампано.

Jovan J. Aleksić

\title{
KOSOVSKA MITROVICA AFTER 1999: LIVING IN A DIVIDED CITY
}

\begin{abstract}
Summary
In 1999, after the NATO bombing, signing of the Kumanovo Agreement and the adoption of Resolution 1244, the withdrawal of the armed forces of the FR of Yugoslavia, the expulsion of more than 250,000 Serbs and other nonAlbanians, the bridge in Kosovska Mitrovica became a scene of constant conflicts between Serbs and Albanians. A large number of Serbs were expelled from various parts of Kosovo and Metohija, as well as from the southern part of this city, settled on its north side, firmly resolving to stay there. On the other side, Albanian extremists from the southern part of the city often carried out attacks on Serbian residents of the northern part of the city, seeking to expel them and take over the last Serbian urban zone in Kosovo and Metohija. Heedful local chroniclers noted that the 118 incidents occurred in the bridge from June 1999 to June 2014, in which Albanians used firearms 26 times. Despite the formal end of the war conflict, it was not possible to speak of this region as a 'post-conflict
\end{abstract}


area' but rather a field of lower-intensity conflict. The border between the 'conflict' and the 'post-conflict' was therefore not clear enough, from which the gray-and-ordinary everyday life of the 'ordinary' inhabitants, with undefined institutional-legal status, extremely unpredictable future, life in almost confused confusion, without any chances for some long-term planning. Facing the most diverse problems in the area of personal and collective security, education, health, culture, utilities, urban planning, spatial planning, electricity and water supply, Serbs from Kosovska Mitrovica were forced to build some kind of their own internal, autonomous, alternative social system, which would enable them to survive in a kind of vacuum in which they had been living since 1999. They drove automobiles, trucks and buses with or without various registration plates, opened independent trade and work shops at locations that were not created for this purpose, used water that was often chemically, filled with bacteria and defective, they fought dark with candles and oil lamps during the multi-time restrictions electricity (mainly in winter), bought milk and dairy products from villagers from the improvised market, many times, and all as one defended the city on the bridge, swallowed a tear gas, received punches and kicks sometimes even bullets, frying an ox on in the city center and shared hot rakia, organized gigs and rock concerts in the open, discussed politics, cheered in slavas, baptisms, weddings, weeping and grieving at the destroyed or desecrated graves of their ancestors. They tried to live a some sort of normal life, although such a way of life was just some sort of his imitation. As everywhere this situation prevails, people simply do everything they can - to survive. 'Survival' may be the key word of this whole story. A word that best describes the opportunities in this city and the population of its inhabitants. 